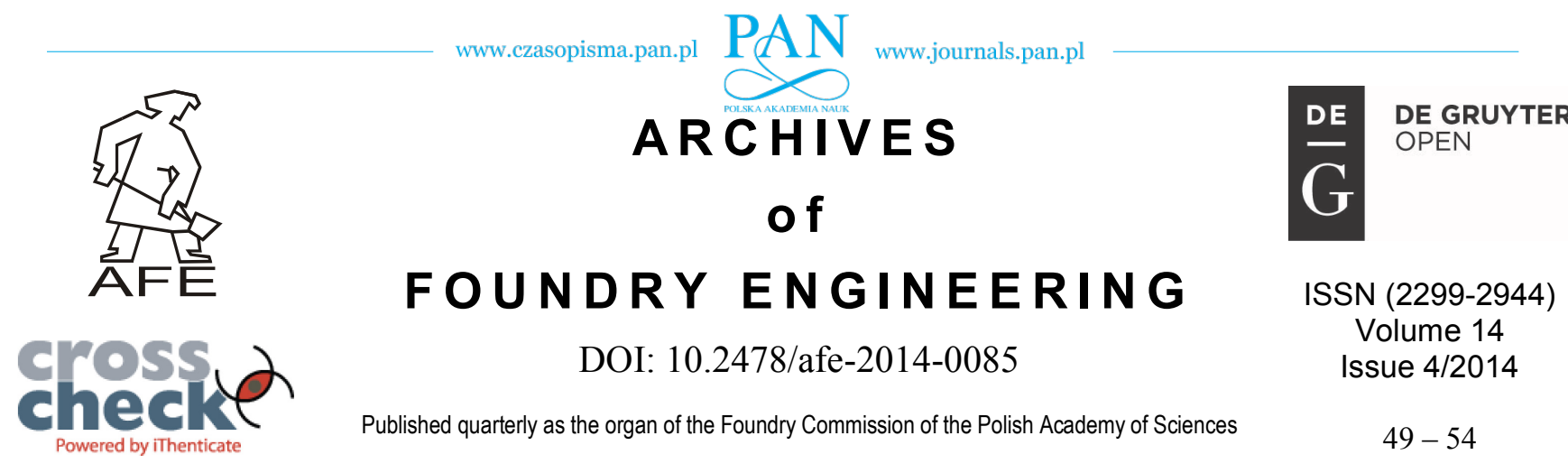

\title{
Austenitization of FerriticDuctile Iron
}

\author{
A.Krzyńska *, A. Kochański \\ Institute of Technology, Faculty of Production Engineering \\ Warsaw University of Technology, Narbutta 85, 02-524 WarsawPOLAND \\ *Corresponding author. E-mail address: a.krzynska@wip.pw.edu.pl
}

Received 01.06.2014; accepted in revised form 15.07.2014

\begin{abstract}
Austenitization is the first step of heat treatment preceding the isothermal quenching of ductile iron in austempered ductile iron (ADI) manufacturing. Usually, the starting material for the ADI production is ductile iron with more convenient pearlitic matrix. In this paper we present the results of research concerning the austenitizing of ductile iron with ferritic matrix, where all carbon dissolved in austenite must come from graphite nodules. The scope of research includedcarrying out the process of austenitization at $900^{\circ} \mathrm{Cusing}$ a variable times ranging from 5 to 240 minutes, and then observations of the microstructure of the samples after different austenitizing times. These were supplemented with micro-hardness testing. The research showed that the process of saturating austenite with carbon is limited by the rate of dissolution of carbon from nodular graphite precipitates.
\end{abstract}

Keywords: Austenitization, Ductile iron, Ferriticmatrix, Matrix structure, ADI

\section{Introduction}

Since ADI was discovered and first commercialized in mid1970 's [1,2] many modifications in technology of heat treatment leading to cost saving and/or properties improvement were proposed. The examples are: Direct Austempered Ductile Iron DADI [3-5], Carbidic Austempered Ductile Iron) - CADI [6-9], Ausformed-Austempered Ductile Iron - AADI [10-11] or even Wall Austempered Ductile Iron - TWADI [12]. However, in all cases the austempering includes at least two main stages, which are: solution heat treatment (austenitizing) and one- or two-step isothermal quenching $[13,14]$ usually carried out in the temperature range of $230-400^{\circ} \mathrm{C}[15-17]$.

Solution heat treatment involves annealing at temperature $800-950^{\circ} \mathrm{C}$ to assure a fully homogeneous structure of the carbonsaturated austenite. According to the literature [18-20], both the temperature and the time of austenitizing have a significant impact on the structure and the properties of ADI. Austenitizing time is a function of process temperature and the type of metal matrix, which may be pearlitic, pearlitic-ferritic or ferritic. Usually, the starting material for the production of ADI is ductile iron of fully pearlitic or pearlitic-ferritic matrix. This type of matrix is very convenient because the carbon needed for austenite saturation comes from cementite, which is a dispersed phase, so that the process of carbon dissolution is relatively fast. In the case of fully ferritic matrix of ductile iron all carbon needed for austenite saturation can be supplied from nodular graphite precipitates. The dissolution is a surface process and a sphere is known as having the lowest surface to volume ratio, this may limit the speed of the process. Moreover, the distance between graphite nodules is incomparably higher than between cementite in pearlite so the time needed for its diffusion must be much longer. On the other hand, ferrite matrix obtained in the casting directly during its solidification (without heat treatment) decreases the shrinkage of the casting. This in turn enables increase in casting yield because of smaller volume of really no feeders [21]. It is obvious that ferritic matrix promotes sound ductile iron casting manufacturing.

It follows from the above that a different type of ductile iron matrix will need a different time for solution heat treatment carried out in the same temperature. It seems reasonable that austenitizing time should be longer in the case of ferritic matrix as compared to the pearlitic one. 
The aim of this paper is to present the results obtained for ferritic ductile cast iron austenitized for different periods of time at temperature $900^{\circ} \mathrm{C}$. The austenitizing temperature was chosen so that, on the one hand, to ensure the maximum saturation of austenite with carbon and, on the other, to prevent excessive growth of austenite grains.

\section{Experimental procedure}

The chemical composition of test samples is shown in table 1 . The specimens, cubes 10x10x10 were cut from the bottom part of the $\mathrm{Y} 2$ type castings.

Table 1.

Chemical composition of specimens

\begin{tabular}{cccccccc}
\hline $\mathrm{C}$ & $\mathrm{Si}$ & $\mathrm{Mn}$ & $\mathrm{P}$ & $\mathrm{S}$ & $\mathrm{Cr}$ & $\mathrm{Cu}$ & $\mathrm{Mg}$ \\
\hline 3,25 & 3,80 & 0,32 & 0,031 & 0,012 & 0,026 & 0,260 & 0,056 \\
\hline
\end{tabular}

All samples were austenitised at the temperature $900^{\circ} \mathrm{C}$. The austenitizing time was: 5, 10,15,30,45,60, $75,90,105,120,240$ minutes. The austenitization was followed by quenching in sand to assure a relatively small cooling rate. Metallographic observations were carried out on samples prepared in a conventional manner by grinding to remove at least the $0.1 \mathrm{~mm}$ thick surface layer. After grinding the specimens were polished and etched with $4 \% \mathrm{HNO}_{3}$ solution in $\mathrm{C}_{2} \mathrm{H}_{5} \mathrm{OH}$. The metallographic observations were carried out with an Olympus IX-70 light microscope using different magnifications and observation modes. The microstructure observations were supplied with hardness measurements. These were carried out using Leitz Wetzlar micro-hardness tester equipped with diamond pyramid loaded $15 \mathrm{~s}$ with $\mathrm{F}=100 \mathrm{~N}$.

\section{Results}

\subsection{Metallography}

Fig. 1 presents the typical microstructure of ductile iron as cast. It consists of graphite nodules embedded in ferrite matrix. Content of pearlite in matrix is around 5\%.

The microstructure of solution heat treated ductile iron is given in fig.2. The micrographs presented in fig. 2 show changes of the microstructures with austenitization time increase. As can be seen from the photos, in all of them the structure of the metallic matrix is composed of ferrite and pearlite, the amount of the last one increase with the time of austenitizing. After 30 minutes of austenitizing the metal matrix is pure pearlitic.

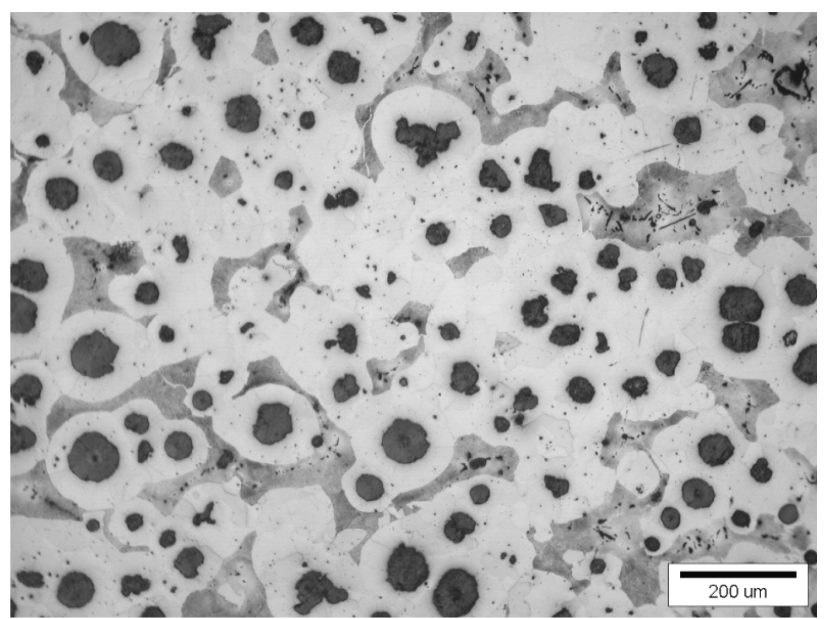

Fig.1.The microstructure of as cast ductile iron

a.

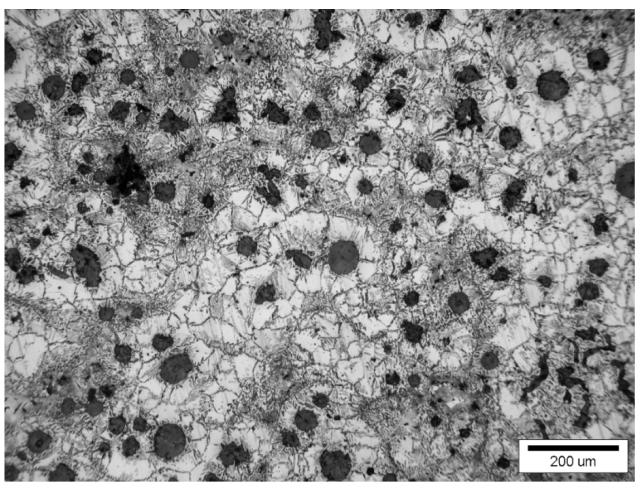

b.

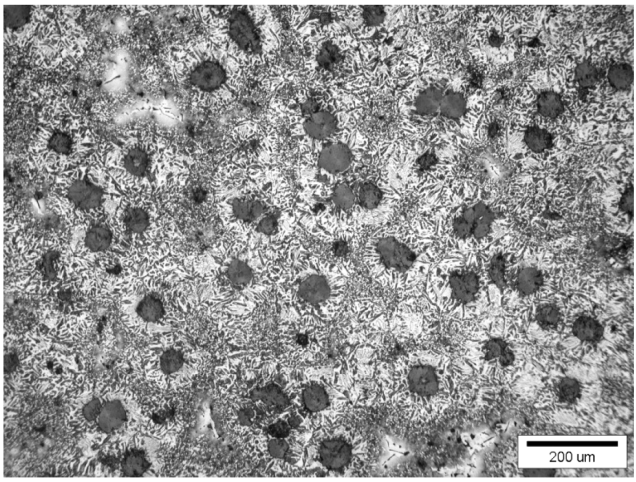

c.

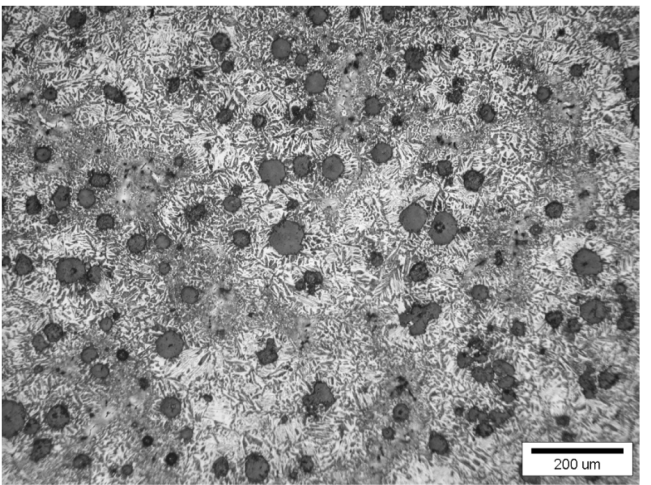


d.

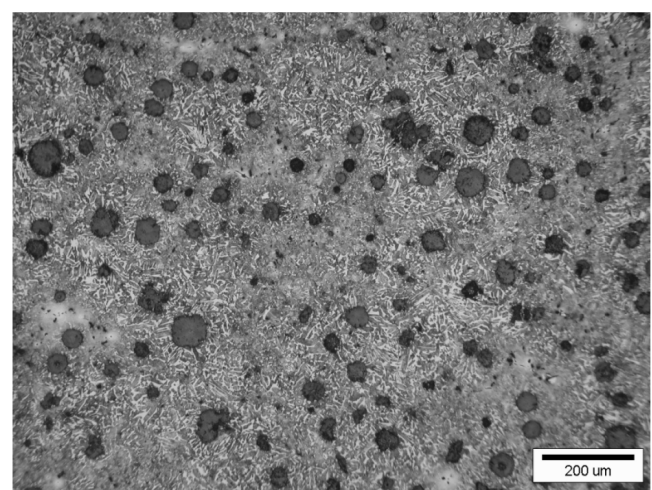

e.

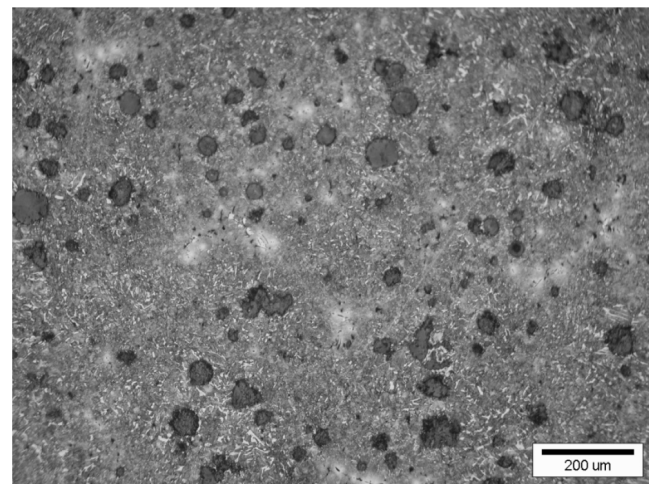

f.

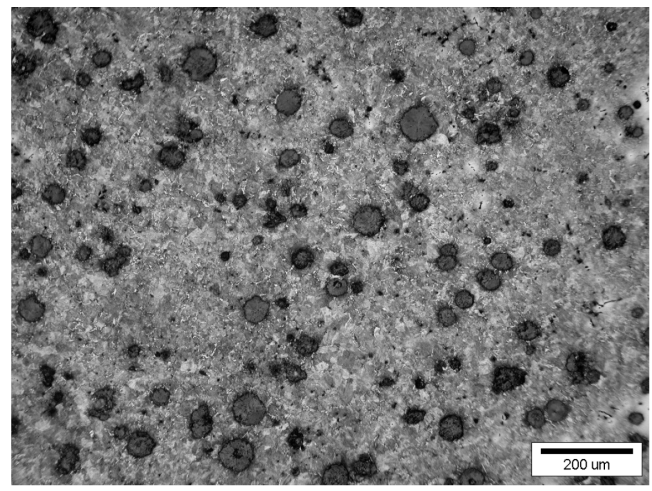

Fig.2. The microstructure of ductile iron after different times of solution heat treatment: $\mathrm{a}-5, \mathrm{~b}-10, \mathrm{c}-15 \mathrm{~d}-30$, e - 45 and $\mathrm{f}-90$ minutes (magnification x100)

A closer look at the matrix microstructure of the casting under consideration shows some differences between the morphology of conventional pearlite and the mixture observed in fig. 2, especially fig. $2 b-d$. These differences are more visible in micrographs taken at a higher magnification from the specimen after 5 minutes austenitization at temperature $900^{\circ} \mathrm{C}$ (fig. 3). a.

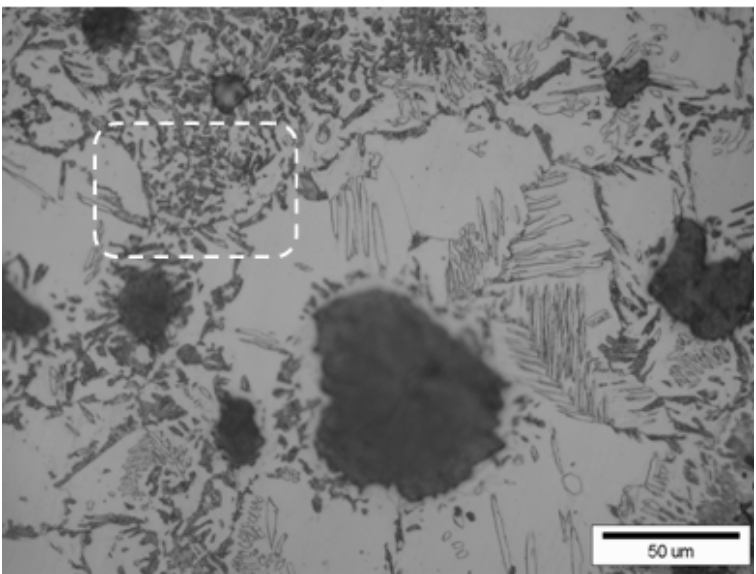

b.

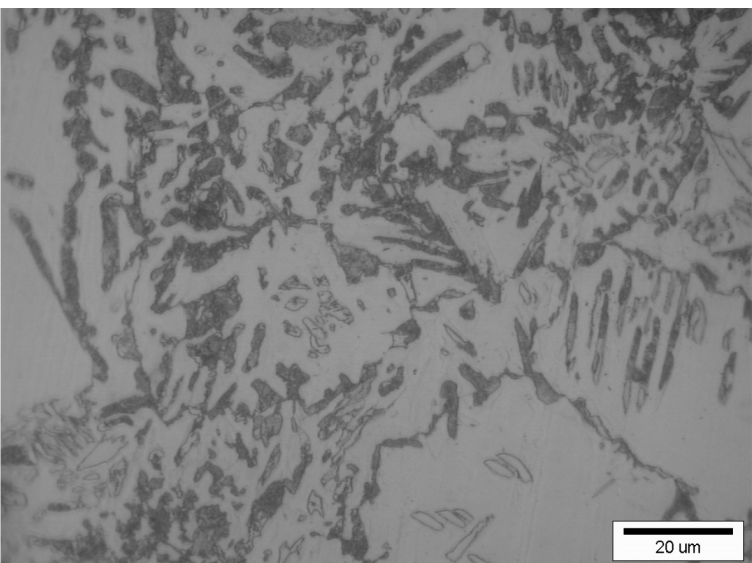

c.

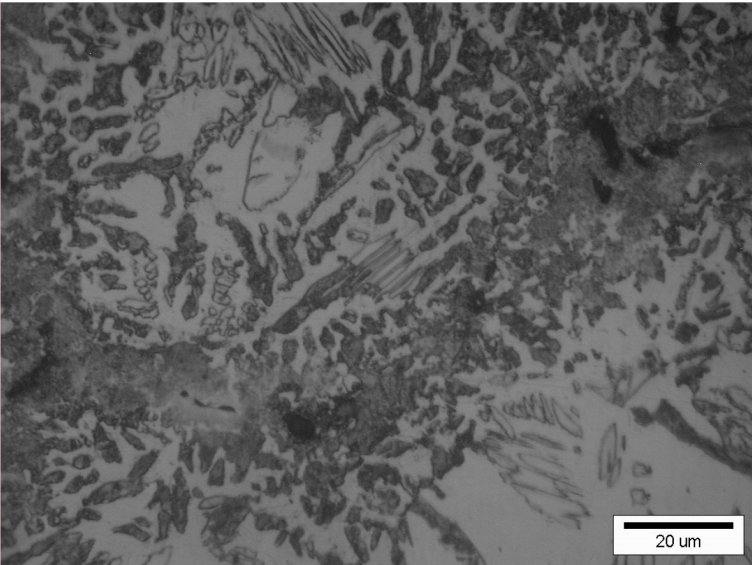

Fig.3. The microstructure of ductile iron after 5 minutes of austenitization: $\mathrm{a}-\mathrm{x} 500, \mathrm{~b}$-magnified part of the microstructure marked in a x1000 and c - x1000 (Nomarski)

If we start with the first photo (fig. 3a), in its central part we can see the graphite nodule precipitate embedded in almost pure ferrite shell. In the immediate vicinity of the graphite nodule very small particles (probably carbides) are visible. Similar particles appearing at the eutectoidal cell boundary form specific chains. Moreover, fine elongated grains forming feather-like patterns with 
the main axes constituting ferrite boundaries are visible in fig. $3 \mathrm{a}$. Although these needle-like precipitates are white in color, they must probably be cementite, which appears in the microstructure depicted in fig. 3b. In this photo (fig. 3b) the area located behind the eutectoidal cell boundary is showed at higher magnification. Here the mixture of cementite in ferrite matrix is clearly visible. The morphology of this mixture looks a little bit different than the typical pearlite but there is no question that it resulted from austenite decomposition. In this area some cementite precipitates are needle-shaped, while others are rather cubic-like (fig. 3c). In case of the last one it cannot be excluded that these carbide precipitates have a different orientation with respect to the metallographic plane.

The presence of similarly shaped ferrite grains was reported by Kowalski and coworkers[22]. According to these authors [22] this ferrite is pre-eutectoid ferrite generated during austenitization in $\mathrm{A}_{1,1}-\mathrm{A}_{1,2}$ temperature range, where austenite, ferrite and carbon are in equilibrium. This is due to the increased concentration of silicon near the graphite. According to the equation proposed by Galarreta and coworkers [23] upper intercritical temperature $T_{c r}{ }^{u p}$ can be determined on the basis of the content of each of the alloy elements.

$T_{c r}{ }^{u}=723-0,3 \mathrm{C}+43 \mathrm{Si}-33 \mathrm{Mn}-6 \mathrm{Cu},{ }^{o} \mathrm{C}$

However, using the formula proposed by Sikora et all in the case of our test cast, intercritical temperature is $873^{\circ} \mathrm{C}$ and it is below the applied austenitizing temperature. On the other hand, the silicon content in the testing alloy was $3.8 \%$, which is a little higher than the applicable range of the equation (3.7\%).

\subsection{Hardness measurements}

Microhardness measurements were performed in order to gain supplementary information which would facilitate the interpretation of the results obtained from the microstructure investigations. The micrographs showed in fig. 4show the examples of the regions where the measurements of microhardness were carried out. The first micrograph (fig. 4a) shows hardness indentation at the area identified as pre-eutectoid ferrite, while that in fig. $4 \mathrm{~b}$ corresponds to pearlite region.

The hardness measured in selected areas was $132 \mu \mathrm{HV}$ and $336 \mu \mathrm{HV}$ respectively. The resulting hardness is distinctly higher than the hardness of ferrite and pearlite, which are usually at the level 80 and $250 \mathrm{HV}$ respectively.

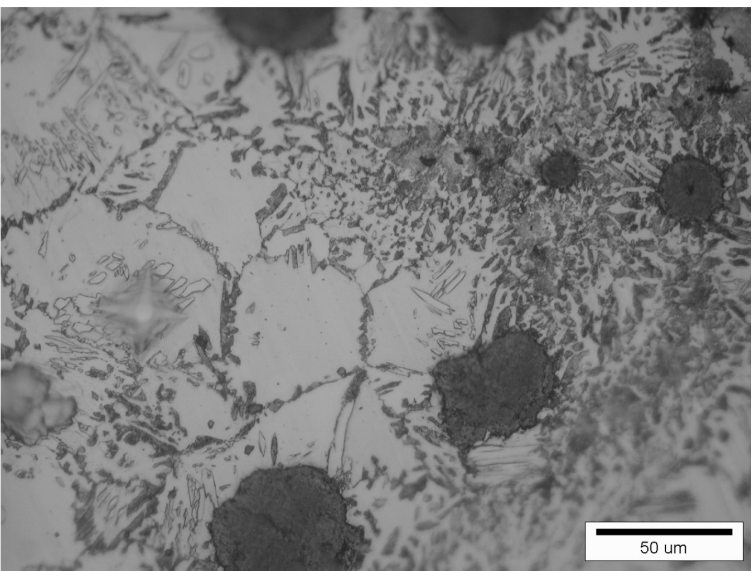

b.

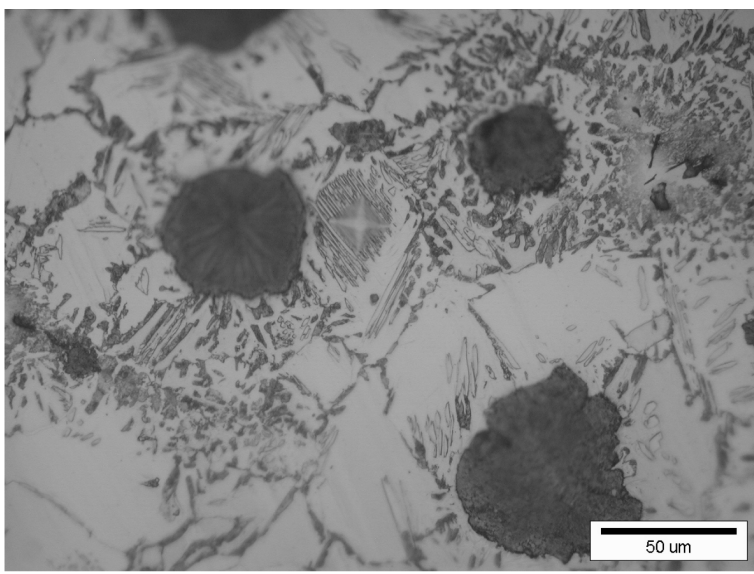

Fig. 4. The microstructure of ductile iron showing the places of microhardness measurements located in: a - ferrite region and $\mathrm{b}$ - pearlite area

\section{Discussion}

In this part we would like to discuss closer some results given above. Firstof all, if we compare the micrograph showed in fig 1 and the set of micrographs in fig. 2, we can see some similarities between the microstructure in fig. 1 and the first three visible in fig. 2 (fig. $2 \mathrm{a}$-c). This similarity is manifested by the white region around graphite nodules, which represent pure ferrite in the case of as cast ductile iron (fig. 1) and is continuously filled with carbide precipitates (fig. 2). The density of the iron carbide precipitates increases with the increase of austenitization time but the white halo is still visible after 15 minutes solution heat treatment and disappears just after 30 minutes (fig. 2d), although presence of relatively large grains of preeutectoidal ferrite may disturb the picture. Now, if we consider the morphology of the constituents visible in fig. 2 , it is worth noting two things. One is the specific distribution of the needle-shaped of preeutectoidal ferrite grains (fig. 2a). There is no question that the grain boundaries work here as preferred sites for nucleation of ferrite and iron carbides. This is nothing surprising if we take into consideration the fact that these are the higher energy regions and also play a role in easy diffusion path. The second point is the 
appearance of very fine particles close to the graphite nodule and similar particles (probably carbides) at the primary austenite grain boundaries.

At this point let us discuss what happens in ductile iron during increasing the solution heat treatment time. As said before, in the case of ferritic ductile iron, the only source of carbon atoms is graphite nodules. So it is obvious that if the temperature reaches an appropriate value, the regions in the immediate vicinity of graphite nodules will be the first to be carburized. With the increase of the austenitization time carbon will diffuse into the region far from the graphite nodules but the concentration of carbon will be different across the distance between two nodules. Saturation and homogenization of carbon concentration in the casting matrix will need some time. A short austenitization time is not sufficient for homogenization and will produce nonuniform ferritic-pearlitic matrix microstructure during slow cooling(fig. 2a). According to fig. 5 [24], during relatively slow cooling, preeutectoidal ferrite will be the first to nucleate, preferably at the grain boundaries of austenite.

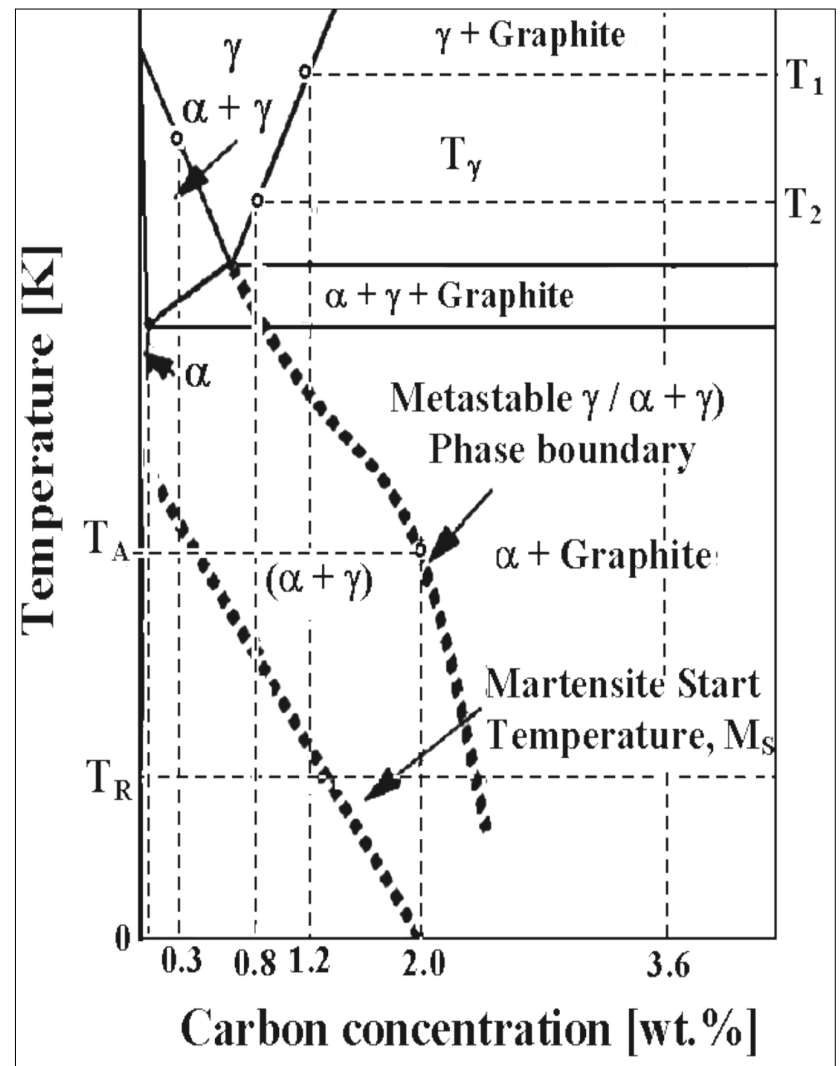

Fig. 5. Schematic phase diagram illustrating the thre-phase region $\alpha+\gamma=$ graphite in case of Fe-C-Si alloy [24]

Its growth will be accompanied with enriching with carbon the area at austenite-ferrite boundary. Depending on carbon concentration, there will be possibility for iron carbide nucleation of carbides. This is not the case for very short time of solution heat treatment but appears when austenitizing time of ductile iron enables saturation of austenite with carbon. Then the process of carbon-saturated austenite decomposition will proceed first with nucleation and growth of preeutectoidal ferrite (see fig. 5), which will be followed by eutectoidal reaction $\gamma \rightarrow \alpha+\mathrm{Fe}_{3} \mathrm{C}$. When the solution heat treatment was long enough for austenite saturation with carbon then the microstructure of ductile iron matrix is ferritic-pearlitic, like the one showed in fig. 6. The appearance of ferrite is cause by primary ferrite precipitation before eutectoidal reaction. The appearance of carbides at primary austenite grain boundaries (fig. 3a) is caused by the fact the grain boundaries play the role of easy diffusion path and simultaneously are the places promoting nucleation process.

a.

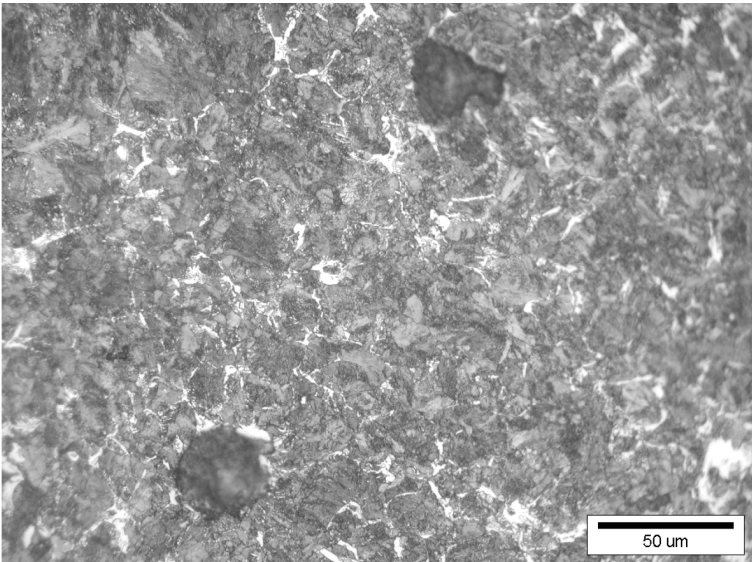

b.

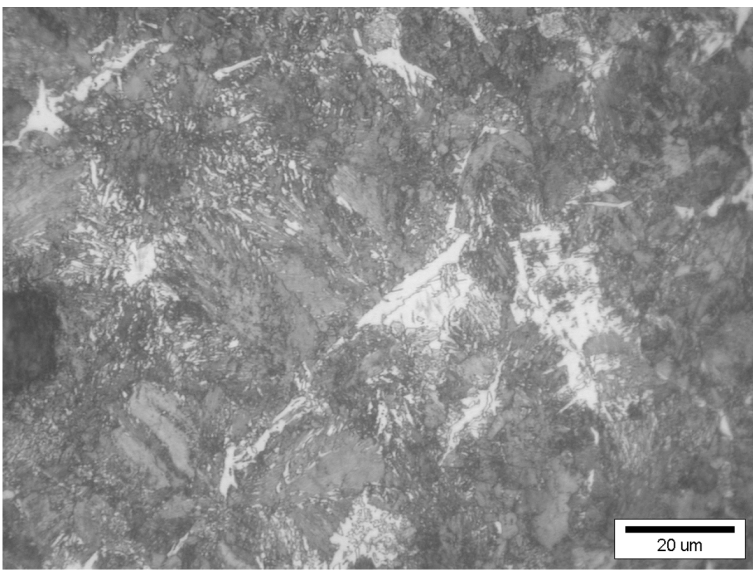

Fig. 6. The microstructure of ductile iron matrix cooled slowly after 90 minutes solution heat treatment at the temperature $900^{\circ} \mathrm{Ca}$ $-\mathrm{x} 500$ and $\mathrm{b}-\mathrm{x} 1000$

\section{Conclusions}

On the basis of the investigation including structure observation, microhardness measurements and discussion of the experimental results following conclusions may be proposed:

1. The solution heat treatment of almost fully ferritic ductile iron with high silicon content at temperature $900^{\circ} \mathrm{C}$ makes possible the saturation of austenite with carbon but the time necessary for it should be no less than 90 minutes. 
2. In the case of high silicon ductile iron some amount of ferrite appears in ductile iron matrix caused by its precipitation at preeutectoidal phase.

3. Pearlite formation in ferritic matrix solid solution heattreated for a relatively short time starts in the region of primary austenite boundaries located far from the carbon nodules. This results from non-uniform concentration of carbon in too shortly austenitized ductile iron.

4. The higher hardness of preeutectoidal ferrite in ductile iron matrix results probably from solid solution strengthening caused by silicon atoms.

\section{References}

[1] 1st International Conference on Austempered Ductile Iron: Your Means to Improved Performance, Productivity, and Cost: 2-4, April, 1984, Hyatt Regency O'Hare, Rosemont (Chicago), Illinois

[2] 2nd International Conference on Austempered Ductile Iron: Your Means to Improved Performance, Productivity and Cost; 17-19 March 1986, Rackham School, University of Michigan, Ann Arbour

[3] Kaczorowski, M.\& Myszka, D. (2005). On the differences between mechanical properties and structure of ductile iron castings Austempered using conventional and direct method. Int. Journal for Manufacturing Science \& Technology. 7(1), 33-39.

[4] Myszka, D. \& Kaczorowski, M. (2006). Microstructure from the surface of investment ADI castings after direct austempering. Archives of Foundry Engineering. 6(18), 350355.

[5] Tybulczuk, J., Myszka, D., Pytel, A., Kowalski, A. \& Kaczorowski, M. (2002). Structural and Mechanical Investigation of Ductile Iron Directly Austempered From the Casting Mould. Archives of Foundry. 2(4),460-467.

[6] Myszka, D. \& Kaczorowski, M. (2002). Carbonitriding as an element of ADI heat treatment. Archives of Foundry. 2(4),408-413

[7] Keough, J.R., \& Hayrynenn, K.L. (2000). Carbidic Austempered Ductile Iron (CADI) DIS Meeting. Nov 14

[8] Laino, S., Sikora, J.A. \& Dommarco,J.R. (2008). Development of Wear Resistant Carbidic Austempered Ductile Iron (CADI) Wear. 265(1-2), 1-7.

[9] Jin Lai, L., Xuexian, Y., Hui, Z. \&Guolu, L. (2008). Application and Prospect of ADI and CADI in Metallurgical and Mine Industries. Modern Cast Iron. 28(4),26-30
[10] Olson, B.N., Brucke, Ch., Parolini, J., Moore, D.J. \& Rundmann, K.B. Ausformed-Austempered Ductile Iron (AADI). International Conference on ADI; DIS and AFS, Louisville, KY, USA, 29-60, Sept. 25-27.

[11] Nasr El-din, H., Nofal, A. \& Ibrahim, M. (2006). Ausforming of Austempered Ductile Iron Alloyed with Nickel. J. of Cast Metals Research. 19(3), 137-150.

[12] Fraś, E., Górny, M. (2006). Structure of Thin Wall Austempered Ductile Iron (TWADI), Proc. 8th Int. Symp. on Science and Processing of Cast Iron (SPCI8), Beijing, China, Oct. 16-19, 157-162.

[13] Kaczorowski, M. \& Krzyńska, A (2005). The study of twostage austempered austempered ductile iron - part I. Archives of Foundry Engineering. 123-130.

[14] Putatunda, S.K. (2001). Development of austempered ductile iron (ADI) with simultaneous high yield strength and fracture toughness by novel two-step austempering process. Mat. Sci Eng. A 315 70-80.

[15] Krzyńska, A. \& Kaczorowski, M.(2010). The studies of mechanical properties and structure of ADI as function of austempering parameters. Archives of Foundry Engineering. 10(4), 41-44.

[16] Krzyńska, A. \& Kaczorowski, M. (2008). The studies of nodular graphite cast iron early stages austempering. Archives of Foundry Engineering. 8(4), 87-92.

[17] Krzyńska, A. \& Kaczorowski, M. (2007). The mystery of ADI. Archives of Foundry Engineering. 7/4. 111-114.

[18] Giętka, T. \& Szykowny, T. (2012). Microstructure and Mechanical Properties of ADI Depending on Austenitization Methods and Parameter. Archives of Foundry Engineering. 12(2), 19-24.

[19] Giętka, T. \& Dymski, S.(2009).Predicting ADI mechanical properties. Archives of Foundry Engineering. 9(3),267-274.

[20] Kapturkiewicz, W. (2004). Modeling of austenityzation kinetics in pearlitic ductile iron. Archives of Foundry.14(4), 204-208.

[21] Karsay,S.(1992). Ductile Iron I Production. The State of Art. QIT-Fer et Titane Inc., Sorelmetal.

[22] Kowalski, A., Kluska-Nawarecka, S. \& Regulski, K.(2013). ADI After Austenitising from Intercritical Temperature. Archives of Foundry Engineering. 13(1)81-88.

[23] Galarreta, A., Boeri, R.E. \& Sikora, J.A. (1997). Free ferrite in pearlite ductile iron - morphology and its influence on mechanical properties. Cast Metals. 9,353-357.

[24] Rundman, K.B. (2004). Proc. 35th Australian Foundry Institute National Conference on Casting Concepts, Adelaide, South Australia, 31.10 - 3.11. 2004. 